\title{
Pozytywne myślenie w rozwoju człowieka
}

\section{POSITIVE THINKING IN HUMAN DEVELOPMENT}

The article is a collection of clinical observations and data from the literature on positive thinking. The author, a psychoanalyst, presents numerous examples of clinical in regarding the positive and negative aspects of this phenomenon. Article prompts to reflection and is a critical recognition of ambiguous phenomenon of positive thinking. This report is a counterweight to too one-sided and therefore unreliable describe this phenomenon.

Key words: positive thinking, affirmation, Seligman, style of explaining, cognitive psychology.

\section{Wstęp}

Niniejsze doniesienie jest próbą krytycznego ujęcia zjawiska pozytywnego myślenia, które jest propagowane w licznych poradnikach psychologicznych jako twórcze i konstruktywne podejście w ramach rozwoju osobistego i wychodzące naprzeciw oczekiwaniom wspólczesnego człowieka i jego stylowi życia. Autor stara się zaprezentować pozytywne i negatywne aspekty tego zjawiska, bazując przede wszystkim na doświadczeniu klinicznym. Próba całościowego ujęcia tego zagadnienia jest odpowiedzią na zbyt jednostronne, a przez to nierzetelne i nieprawdziwe opracowanie tego konceptu, jaki często dominuje w literaturze przedmiotu. 


\section{Zagadnienia definicyjne}

Pozytywne myślenie polega na świadomym koncentrowaniu się na pozytywach tego, co nas otacza: ludzi, zdarzeń i sytuacji. Pozytywne myślenie to także opieranie się na mocnych stronach drugiego człowieka, umiejętność dostrzegania w innych i w sobie potencjałów i zasobów. Definicja ta już w swojej treści zakłada pewne przekłamanie i selektywność spostrzegania: koncentrujemy się na tych elementach zdarzeń, ludzi i sytuacji, które mają walor pozytywny, a unikamy wszelkich elementów negatywnych, które by ten obraz mogły zakłócić. Obraz rzeczywistości, jaki wtedy dociera do naszej świadomości jest jednostronny, choć z założenia ma to przynieść określone pozytywne skutki dla całościowego funkcjonowania człowieka i poprawy jego kondycji psychicznej. Powstaje tu jednak zasadnicza wątpliwość; czy można uzyskać rzeczywiste, pozytywne efekty swoich działań czy poprawić samoocenę na bazie jednostronnej oceny, czy selektywnego odbioru rzeczywistości wewnętrznej i zewnętrznej?

Pozytywne myślenie składa się z dwóch umiejętności: wiary w pozytywny skutek działania, a także zdolności dokonywania operacji myślowych, dzięki którym będziemy potrafili przeżywać zdarzenia nieprzyjemne jako zdarzenia służące rozwojowi i zmianie na lepsze. I tu wchodzimy w zakres obszaru psychomanipulacji: żeby osiągnąć zamierzony efekt, czyli poprawę samopoczucia i lepszą skuteczność naszych działań, musimy w coś mocno wierzyć, a po drugie, umieć przekształcać coś, co budzi w nas adekwatne reakcje negatywne na coś pozytywnego, konstruktywnego. Czy zatem nie jest to kolejna próba specyficznego „oszustwa”, jakiego dokonujemy na psychice? Z jednej strony zapewne tak jest, ale patrząc z perspektywy klinicznej, taka umiejętność przekształcania niekorzystnych zdarzeń w coś konstruktywnego jest w pewnym sensie zjawiskiem pozytywnym. Jest to sposób doszukiwania się w realnie kryzysowych czy dramatycznych wydarzeniach, czegoś, co odmieni los na lepsze, co zmusi nas do zmiany hierarchii wartości, sprowokuje do przełamania stereotypów myślenia na swój temat. Tak np. utrata pracy jest bardzo stresującym i zwykle negatywnie odbieranym doświadczeniem, ale umiejętność przekształcenia tego doświadczenia w coś pozytywnego czy też spojrzenie na to wydarzenie $\mathrm{z}$ różnych perspektyw, pozwala człowiekowi odnaleźć w tym sens i skłonić go, a wręcz czasami wymusić na nim działania, które do tej pory były zupełnie nie brane pod uwagę. Może się bowiem okazać, że konieczność poszukiwania nowej pracy na skutek jej utraty, stała się jedyną okazją do realnej zmiany na lepsze, 
do ponownej „walki” o siebie, swoje potrzeby, o ponowne zainteresowanie się sobą.

Zdolność do zauważania pozytywnych aspektów sytuacji to jeden Antropologia teologiczna ze wskaźników zdrowia psychicznego. Można zatem założyć, że ludzie posiadający tę umiejętność, łatwiej osiągną stan równowagi psychicznej nawet w realnie niekorzystnych warunkach. Z kolei nadmierna zdolność do spostrzegania świata w ciemnych barwach jest przykładem depresyjnej bądź masochistycznej postawy, bądź też może z niej wynikać.

\section{Konstruktywne konsekwencje pozytywnego myślenia w ujęciu Seligmana}

Seligman w książce Optymizmu można się nauczyć ${ }^{1}$ podaje liczne przykłady konstruktywnego wpływu pozytywnego myślenia na funkcjonowanie człowieka w wielu obszarach życia. Posługuje się w tym celu pojęciem stylów wyjaśniania. Przyjęty styl decyduje o tym czy ktoś stanie się bardziej optymistyczny w spostrzeganiu rzeczywistości czy też bardziej pesymistyczny. To z kolei ma wpływ na efektywność jego pracy i jakość interakcji międzyludzkich. Oto niektóre przykłady tych zależności:

- Optymiści wyjaśniając przyczyny pomyślnych wydarzeń skłonni są traktować je jako czynniki stałe, doszukując się ich w trwałych cechach, które działają przez cały czas. W tym przypadku postawa optymistyczna może mieć dwa oblicza: z jednej strony koncentracja na mocnych stronach i uważanie ich za wartości trwałe może wpłynąć dodatnio na wiarę w skuteczność działań, z drugiej strony, taka postawa stwarza ryzyko braku samokrytycyzmu i przeceniania własnych możliwości. Można wtedy nie dostrzec realnych zagrożeń, bezgranicznie ufając w swoje szczęście i powodzenie, narażając siebie i innych. Innymi słowy, postawa nieuzasadnionego optymizmu może być czasami ryzykowna i nieść za sobą realne zagrożenia.

- Optymista uważa, że niepomyślne wydarzenia mają przyczyny o ograniczonym zasięgu, natomiast wydarzenia pomyślne wpływają korzystnie na jego wszelkie poczynania. Takie podejście nie jest realnym odbiciem rzeczywistości, ale poprzez takie nastawienie, może czasami przynieść pozytywne skutki.

- Optymiści nie poddają się bezradności, co wzmacnia system immunologiczny i sprzyja zachowaniu dobrej kondycji psychofizycznej.

M. Seligman, Optymizmu można się nauczyć, Poznań 2002. 
- Należy pamiętać, że optymistyczny styl wyjaśniania nie może być utożsamiany z postawą nonszalancji, nieuzasadnionej pewności siebie czy brakiem samokrytycyzmu.

\section{Meandry i zagrożenia pozytywnego myślenia}

Ksiądz Aleksander Posacki w artykule Plaga pozytywnego myślenia ${ }^{2}$ bardzo krytycznie podchodzi do zjawiska pozytywnego myślenia. Konstatuje on, że myślenie pozytywne jest przedstawiane zwykle jako bezgraniczna i magiczna wiara w moc słowa i nieskończone, czy wręcz boskie możliwości człowieka. Przeciwieństwem jest tu tzw. myślenie negatywne (obciążone odpowiedzialnością za wszelkie nieszczęścia i choroby ludzkie). Zalicza się do niego nawet wszelką refleksję nad złem, grzechem, winą i cierpieniem czy śmiercią, co - z punktu widzenia choćby kultury - zubaża obraz człowieka i banalizuje powage jego egzystencji.

W swoim artykule ks. Posacki przeciwstawia myślenie życzeniowe, jakim jest ideologia pozytywnego myślenia - prawdzie. Ideologia ta sprzyja tłumieniu prawdziwych uczuć, podobnie jak liczenie na efekt placebo czy autosugestię w przypadku poważnych zaburzeń somatycznych. A do rozwoju potrzebne są tak pozytywne jak i negatywne emocje

Z klinicznego punktu widzenia, nieprawidłowo rozumiane i realizowane pozytywne myślenie może czasem prowadzić do spłycenia i zawężenia obrazu samego siebie, nieskutecznej eliminacji tego, co niewygodne, słabe, a więc w pewnym sensie staje się automanipulacją psychiczną.

Pozytywne myślenie może być czasami formą utraty kontaktu z rzeczywistością, zarówno wewnętrzną jak i zewnętrzną i w związku z tym ignorowaniem i lekceważeniem „rzeczywistych wrogów” osłabiających rozwój.

Siła człowieka wynika ze świadomości realnego obrazu siebie, a więc zarówno z brania pod uwagę mocnych jak i słabych stron i w pokonywaniu „negatywnej części” poprzez konkretną walkę z nimi, a nie mentalne usuwanie ich jako przeszkody w osiąganiu sukcesu. Nadajemy „wrogowi” dodatkowej mocy, jeśli walkę z nim ograniczymy do zaprzeczenia jego istnieniu. Dlatego tak ważne np. w metodzie psychoanalitycznej jest odsłanianie części nieświadomej, by podjąć realną konfrontację z tymi siłami. Jest to właściwa droga do wzmocnienia ego i kontroli nad tymi siłami. Należy pamiętać, że „wróg”, który nie jest

A. Posacki, Psychologia i New Age. Psychologiczne terapie czy okultystyczne inicjacje, Gdańsk, 2007. 
poznany, zaczyna być demonizowany i nadajemy mu niebotyczną siłę, często przekraczającą realne zagrożenie.

\section{Psychologiczne bariery stosowania pozytywnego myślenia}

Przyjmując założenie, że generalnie pozytywne myślenie ma dobroczynny wpływ na rozwój człowieka i realizację jego pragnień, należy zadać pytanie, dlaczego ludzie często nie korzystają z tego „dobrodziejstwa” i kontynuują linię „,autodestrukcji”. Oto tylko niektóre z powodów takiego stanu rzeczy:

1. Traktowanie pozytywnego myślenia jako płytkiego, manipulacyjnego sposobu polepszania swojego samopoczucia, czyli niewiara w skuteczne działanie tego typu technik. Często jest to utożsamiane z infantylnością, „drogą na skróty”, brakiem refleksyjności itp.

2. Niechęć do jakichkolwiek form ,programowania” siebie i narzucania sobie komunikatów i sposobów myślenia bez uwzględnienia własnej specyfiki i indywidualności. Takie programowanie oznacza dla wielu ludzi formę zniewolenia, na co nie wyrażają zgody.

3. Głęboka niewiara w poprawę swego losu, często wzmocniona przez skłonności depresyjne czy masochistyczne. Pozytywne myślenie koliduje zatem $\mathrm{z}$ ogólnym obrazem siebie i niwelowane jest przez zaburzenia osobowości. Silniejsza u tego typu ludzi będzie tendencja do podtrzymywania takiego wizerunku siebie, czyli gromadzenie i interpretowanie doświadczeń w taki sposób, by umocnić przekonanie o swojej bezradności i niemocy wobec losu.

4. Niechęć do realizacji zasad ,pozytywnego myślenia” może wpisywać się w masochistyczny konstrukt osobowości, a także może ułatwiać akceptację rywalizacyjnych i zawistnych uczuć w stosunku do innych ludzi. Innymi słowy, pogłębianie autodestrukcji może stać się dobrym alibi do zaistnienia negatywnych uczuć wobec innych. Im będzie mi gorzej, tym bardziej będę usprawiedliwiony okazując negatywne uczucia wobec tych, którym się powodzi, którym lepiej się wiedzie.

5. Odrzucanie czegoś, co może być pomocne i konstruktywne może mieć swoje uzasadnienie w chronicznym poczuciu winy i negacji siebie. Każda forma przyniesienia sobie ulgi, czy poprawy samopoczucia będzie odrzucana i negowana, bowiem nieprzepracowane poczucie winy może prowadzić do anhedonii. Pozytywne myślenie jest w tym przypadku czymś na co dana osoba nie zasługuje, nie jest tego warta, jej życie zaczyna przybierać formę pokuty i ma być tak przeżywane, by to poczucie winy redukować. 
Oczywiste jest, że poprzez pozytywne myślenie nie można by osiągnąć tego celu.

6. Opór w stosowaniu pozytywnego myślenia może mieć też swoje źródło w trudności akceptacji siebie jako kogoś afirmującego życie, szczęśliwego czy spełnionego. Powodem przyjęcia takiej postawy mogą być doświadczenia krytykowania stanu szczęśliwości przez innych bądź jego negowanie. Konsekwencją może być przeżywanie pozytywnych uniesień wewnątrz siebie, a na zewnątrz prezentowanie cierpienia, niepowodzenia, braku satysfakcji. Taka postawa jest często pochodną wychowania, gdzie okazywanie zadowolenia, szczęśliwości, powodzenia jest krytykowane i traktowane jako wywyższanie siebie.

7. Kolejnym psychologicznym powodem rezygnacji ze stosowania pozytywnego myślenia może być przewaga destrukcyjnych, patologicznych elementów w osobowości. Świadomość i możliwości poprawy swojego położenia przegrywają z tendencjami autodestrukcyjnymi. Dysponując zatem określonymi narzędziami pomocy, nie potrafimy z nich skorzystać, co dostarcza cierpienia i może pogłębić bezradność i niemoc.

Pozytywne myślenie to zagadnienie wieloznaczne w swojej treści. Posiada zarówno aspekty pozytywne i negatywne. To, jakie aspekty będą przeważać, w dużym stopniu zależy od tego jak to „narzędzie” będzie stosowane. Niewątpliwie najcenniejszym atutem tego sposobu myślenia jest umiejętność odnajdywania w realnie negatywnych, traumatycznych doświadczeniach czegoś pozytywnego, rozwojowego. Poszerzenie obrazu tego, co doświadczamy pomaga podejmować racjonalne decyzje, a często wymusza na człowieku podjęcie działań, które wcześnie z różnych powodów nie były brane pod uwagę. Ciemna strona pozytywnego myślenia to zakłamywanie rzeczywistości, oszukiwanie samego siebie, selektywne przeżywanie, a więc umacnianie w sobie nierealnego obrazu siebie i otaczającego świata.

Słowa kluczowe: pozytywne myślenie, afirmacja, Seligman, style wyjaśniania, psychologia poznawcza.

\section{Bibliografia:}

1. Kokoszka A., Wprowadzenie do terapii behawioralno-poznawczej. Kraków 2009.

2. Mello A., Przebudzenie, Poznań 1990.

3. Murphy J., Potęga podświadomości, Warszawa 2013. 
4. Oleś P. (red.), Wybrane zagadnienia z psychologii osobowości, Lublin 1997.

5. Peale N., Moc pozytywnego myślenia, Warszawa 1993.

6. Posacki A., Psychologia i New Age. Psychologiczne terapie czy okultystyczne teologiczna inicjacje, Gdańsk 2007.

7. Seligman M., Optymizmu można się nauczyć, Poznań 2002. 